\title{
Pengaruh Self Efficacy, Motivasi, Kompensasi, dan Kepuasan Kerja terhadap Kinerja Karyawan
}

\author{
*Dian Nur Aprilia ${ }^{1}$, Prayekti ${ }^{2}$, Kusuma Candra Kirana ${ }^{3}$ \\ ${ }^{1}$ Universitas Sarjanawiyata Tamansiswa \\ *diannurda@gmail.com
}

\begin{abstract}
This paper will discuss the effect of work motivation for the performance of the Gunungkidul Regional Secretariat staff. The purpose of These papers are: 1. Does self-efficacy affect employee performance? 2. Does motivation affect employee performance? 3. Does Compensation affect employee performance? 4. Does job satisfaction affect employee performance? 5. Do the variables of self-efficacy (X1), motivation (X2), compensation (X3) and job satisfaction (X4) simultaneously affect employee performance (Y)? Gunungkidul Regional Secretariat and The population is 80 all employees at the Gunungkidul Regional Secretariat. Total sample 80 respondents were taken using the accidental sampling technique method. Data analyzed using multiple linear regression. The results obtained by Self efficacy have a positive effect on employee performance. Motivation has a positive effect on employee performance Compensation has a positive effect on employee performance Job satisfaction has a positive effect on employee performance Self-efficacy, motivation, compensation and job satisfaction simultaneously influence employee performance.
\end{abstract}

Keywords : self-efficacy; motivation; compensation ; job satisfaction; employee performance.

\begin{abstract}
ABSTRAK
Tulisan ini akan membahas efek motivasi kerja terhadap kinerja staf Sekretariat Daerah Gunungkidul. Tujuan makalah ini adalah: 1. Apakah kemanjuran diri mempengaruhi kinerja karyawan? 2. Apakah motivasi mempengaruhi kinerja karyawan? 3. Apakah Kompensasi mempengaruhi kinerja karyawan? 4. Apakah kepuasan kerja mempengaruhi kinerja karyawan? 5. Apakah variabel kemanjuran diri (X1), motivasi (X2), kompensasi (X3) dan kepuasan kerja (X4) secara bersamaan mempengaruhi kinerja karyawan (Y)? Sekretariat Daerah Gunungkidul dan Penduduk adalah 80 seluruh pegawai di Sekretariat Daerah Gunungkidul. Total sampel 80 responden diambil menggunakan metode teknik pengambilan sampel yang tidak disengaja. Data dianalisis menggunakan beberapa regresi linear. Hasil yang diperoleh dengan Kemanjuran diri memiliki efek positif terhadap kinerja karyawan. Motivasi memiliki efek positif pada kinerja karyawan Kompensasi memiliki efek positif pada kinerja karyawan Kepuasan kerja memiliki efek positif pada kinerja karyawan Kemanjuran diri, motivasi, kompensasi dan kepuasan kerja secara bersamaan mempengaruhi kinerja karyawan
\end{abstract}

Kata Kunci : Self Efficacy, Motivasi, Kompensasi, Kepuasan Kerja, Kinerja Karyawan

\section{PENDAHULUAN}

Di era perkembangan globalisasi saat ini banyak adanya perubahan - perubahan ekonomi yang membuat perusahaan melakukan rektrukturisasi. Sumber daya manusia dianggap salah satu elemen penting bagi perusahaan untuk bertahan di era globalisasi dan meningkatkan kompetensi untuk menunjang keberlangsungan suatu perusahaan. Handoko (2001:133) menyatakan bahwa sumber daya terpenting bagi suatu organisasi adalah sumber daya manusia yaitu orang yang memberi tenaga, bakat, kreativitas, dan usaha mereka pada organisasi.

Salah satu hal yang dapat mempengaruhi kinerja adalah self efficacy dengan adanya self efficacy yang tinggi maupun yang rendah akan berpengaruh pada kinerja yang dilakukan oleh 
setiap individu, hal tersebut juga berpengaruh terhadap baik buruknya kinerja yang dilakukan oleh karyawan. Lee dan Bobko (1994) dalam Engko (2008) individu yang memiliki self efficacy yang cenderung lebih maka akan bisa meningkatkan kinerja dalam suatu perusahaan .

Selain self efficacy ada juga hal penting yang berpengaruh terhadap kinerja karyawan yaitu motivasi, dengan adanya motivasi dari perusahaan maka akan mempengaruhi kinerja dari karyawan sehingga karyawan lebih semangat dan akan menghasilkan kinerja yang lebih optimal. Menurut Burney dalam Oluseyi dan Ayo (2009) menyatakan bahwa tingkat kinerja tidak hanya berdasarkan pada kemampuan aktual tetapi juga berdasarkan tingkat motivasi yang mereka tunjukkan pada suatu perusahaan. Selain motivasi kompensasi juga berpengaruh terhadap kinerja bagi perusahaan, baik berpengaruh positif maupun negatif adanya kompensasi dapat meningkatkan kinerja maupun menurunkan kinerja karyawan, jadi pemberian kompensasi di dalam perusahaan harus secara adil dan benar sesuai kemampuan yang akan diberikan oleh karyawan terhadap perusahaan.

Sedangkan pada penelitian ini melakukan penelitian sejumlah empat variable yaitu self efficacy, motivasi, kompensasi, dan kepuasan kerja terhadap kinerja karyawan untuk mengetahui bagaimana pengaruh dari keempat variable tersebut apakah berpengaruh atau tidak terhadap kinerja karyawan.

\section{KAJIAN LITERATUR}

Menurut Bandura (2000) dalam Gunawan dan Susanto (2013) mendefinisikan self efficacy merupakan rasa kepercayaan seseorang bahwa individu dapat menunjukkan perilaku yang dituntut dalam suatu situasi yang sedang terjadi. Motivasi menurut pengertian berasal dari kata latin movere yang berarti dorongan atau menggerakkan. Motivasi (motivation) di dalam manajemen hanya ditujukan pada sumber daya manusia umumnya dan bawahan khususnya. "Berendoom dan Stainer dalam Sedarmayanti (2000:20) mendefinisikan "motivasi merupakan kondisi mental yang akan mendorong aktivitas dan memberikan energi yang mengarah kepada pencapaian kebutuhan yang akan memberikan kepuasan atau mengurangi ketidakseimbangan".

Menurut Umar (2008), kompensasi adalah sesuatu yang diterima oleh karyawan dalam bentuk seperti gaji atau upah, bonus, premi, pengobatan, asuransi, dan lain-lain yang sejenis yang dibayar oleh organisasi. M.yani (2012) juga berpendapat bahwa kompensasi adalah segala sesuatu yang diterima karyawan sebagai balas jasa untuk kerja mereka. Robbins (2003).Kepuasan kerja terjadi apabila kebutuhan-kebutuhan individu sudah terpenuhi dan terkait dengan derajat kesukaan dan ketidaksukaan karyawan sesuai dengan tingkat karyawan. Hal ini merupakan sikap umum yang dimiliki oleh karyawan yang erat kaitannya dengan imbalan yang mereka yakini akan diterima setelah melakukan sebuah pengorbanan.

Dimensi Kepuasan Kerja Menurut Luthan (dalam Kaswan, 2012), enam dimensi pekerjaan yang telah diidentifikasi untuk merepresentasikan karakteristik pekerjaan yang paling penting dimana karyawan memiliki respon afektif. Keenam dimensi tersebut adalah: Pekerjaan itu sendiri, dalam hal ini pekerjaan memberikan tugas menarik, kesempatan untuk belajar, dan kesempatan untuk menerima tanggung jawab. Gaji, sejumlah upah atau gaji yang diterima dan tingkat dimana hal ini bisa dipandang sebagai hal yang dianggap pantas dibandingkan dengan orang lain dalam organisasi. Brahmasari (2008) mengemukakan bahwa kinerja adalah pencapaian atas tujuan organisasi yang dapat berbentuk output kuantitatif maupun kualitatif, kreatifitas, fleksibilitas, dapat diandalkan, atau hal-hal lain yang 
diinginkan oleh organisasi.

\section{METODE PENELITIAN}

Penelitian ini dilakukan pada Kantor Sekretariat Daerah Kabupaten Gunungkidul. Populasi dalam penelitian ini berjumlah 80 karyawan Kantor Sekretariat Daerah Kabupaten Gunungkidul. Teknik Pengambilan sampel menggunakan teknik sampling aksidental adalah teknik penentuan sampel berdasarkan kebetulan, yaitu siapa saja yang secara kebetulan bertemu dengan peneliti dapat digunakan sebagai sampel, bila dipandang orang yang kebetulan ditemui itu cocok sebagai sumber data (Sugiyono, 2001). Menurut Margono (2004)

Metode pengumpulan data menggunakan angket atau kuesioner. Kuesioner ini ialah sebuah teknik pengumpulan data yang dilakukan dengan cara memberikan beberapa pertanyaan tertulis kepada subjek penelitian terkait dengan topik yang akan diteliti. Data primer merupakan data yang didapat dari sumber, dari individu atau perseorangan, dengan cara mengisi kuesioner. dimana data primer adalah data yang diperoleh dari hasil penelitian langsung di lapangan pada perusahaan yang menjadi objek penelitian. Daftar pertanyaan dalam kuesioner ini harus sesuai dengan permasalahan yang diteliti dan memperoleh data berkaitan dengan motivasi instrinsik, pelatihan, kompensasi finansial, dan kinerja individual karyawan. Menurut Sugiyono (2010) skala yang digunakan dalam kuesioner adalah skala likert 1-4 dengan penjelasan sebagai berikut:

1. SS : Sangat setuju skor 4

2. $S \quad$ : Setuju skor 3

3. TS : Tidak setuju skor 2

4. STS : Sangat tidak setuju skor 1

\section{HASIL DAN PEMBAHASAN}

4.1 Karakteristik Responden Berdasarkan Jenis Kelamin

Tabel 1 . Jenis Kelamin

\begin{tabular}{lll}
\hline Kategori & Frekuensi & $\begin{array}{c}\text { Prosentase } \\
\%\end{array}$ \\
\hline Laki-laki & 62 & $\mathbf{8 0 . 0}$ \\
Perempuan & 18 & $\mathbf{2 0 . 0}$ \\
Total & $\mathbf{8 0}$ & $\mathbf{1 0 0 . 0}$ \\
\hline
\end{tabular}

Sumber: hasil olah data 2020

Berdasarkan tabel 1 dapat diketahui bahwa karakteristik responden berdasarkan jenis kelamin, sebagian besar responden adalah laki-laki yaitu sebanyak 62 responden (80\%). 
4.2 Karakteristik Responden Berdasarkan Pendidikan Terakhir

Tabel 2 . Jenis Kelamin

\begin{tabular}{|c|c|c|}
\hline Kategori & Frekuensi & Prosentase \% \\
\hline S1 & 54 & 60.0 \\
\hline S2 & 26 & 40.0 \\
\hline Total & 80 & 100.0 \\
\hline
\end{tabular}

Sumber: hasil olah data 2020

Berdasarkan tabel 2 dapat diketahui bahwa karakteristik responden berdasarkan pendidikan terakhir, sebagian besar responden adalah menempuh pendidikan S1 yaitu sebanyak 54 responden $(60 \%)$

4.3 Uji Kualitas Data

Table 3 . Hasil Uji Validitas Dari Item-Item Variabel Penelitian

\begin{tabular}{|c|c|c|c|c|}
\hline Variabel & $\begin{array}{c}\text { Item } \\
\text { Pertanyaan }\end{array}$ & $\begin{array}{c}\mathrm{r} \\
\text { hitung }\end{array}$ & $\begin{array}{c}\mathrm{r} \\
\text { tabel }\end{array}$ & Keterangan \\
\hline \multirow{8}{*}{$\begin{array}{c}\text { Self } \\
\text { Efficacy }\end{array}$} & $\mathrm{X} 1.1$ & 0,618 & 0,219 & Valid \\
\hline & $\mathrm{X} 1.2$ & 0,695 & 0,219 & Valid \\
\hline & $\mathrm{X} 1.3$ & 0,728 & 0,219 & Valid \\
\hline & $\mathrm{X} 1.4$ & 0,517 & 0,219 & Valid \\
\hline & $\mathrm{X} 1.5$ & 0,587 & 0,219 & Valid \\
\hline & $\mathrm{X} 1.6$ & 0,556 & 0,219 & Valid \\
\hline & $\mathrm{X} 1.7$ & 0,603 & 0,219 & Valid \\
\hline & $\mathrm{X} 1.8$ & 0,759 & 0,219 & Valid \\
\hline \multirow{8}{*}{ Motivasi } & $\mathrm{X} 2.1$ & 0,705 & 0,219 & Valid \\
\hline & $\mathrm{X} 2.2$ & 0,519 & 0,219 & Valid \\
\hline & $\mathrm{X} 2.3$ & 0,580 & 0,219 & Valid \\
\hline & $\mathrm{X} 2.4$ & 0,669 & 0,219 & Valid \\
\hline & $\mathrm{X} 2.5$ & 0,546 & 0,219 & Valid \\
\hline & $\mathrm{X} 2.6$ & 0,544 & 0,219 & Valid \\
\hline & $\mathrm{X} 2.7$ & 0,659 & 0,219 & Valid \\
\hline & $\mathrm{X} 2.8$ & 0,523 & 0,219 & Valid \\
\hline \multirow{8}{*}{ Kompensasi } & X3.1 & 0,621 & 0,219 & Valid \\
\hline & X3.2 & 0,544 & 0,219 & Valid \\
\hline & X3.3 & 0,700 & 0,219 & Valid \\
\hline & X3.4 & 0,602 & 0,219 & Valid \\
\hline & $\mathrm{X} 3.5$ & 0,509 & 0,219 & Valid \\
\hline & X3.6 & 0,394 & 0,219 & Valid \\
\hline & X3.7 & 0,705 & 0,219 & Valid \\
\hline & $\mathrm{X} 3.8$ & 0,624 & 0,219 & Valid \\
\hline \multirow{5}{*}{$\begin{array}{c}\text { Kepuasan } \\
\text { Kerja }\end{array}$} & $\mathrm{X} 4.1$ & 0,606 & 0,219 & Valid \\
\hline & $\mathrm{X} 4.2$ & 0,615 & 0,219 & Valid \\
\hline & $\mathrm{X} 4.3$ & 0,607 & 0,219 & Valid \\
\hline & $\mathrm{X} 4.4$ & 0,647 & 0,219 & Valid \\
\hline & $\mathrm{X} 4.5$ & 0,644 & 0,219 & Valid \\
\hline
\end{tabular}




\begin{tabular}{ccccc}
\hline Variabel & $\begin{array}{c}\text { Item } \\
\text { Pertanyaan }\end{array}$ & $\begin{array}{c}\mathrm{r} \\
\text { hitung }\end{array}$ & $\begin{array}{c}\mathrm{r} \\
\text { tabel }\end{array}$ & Keterangan \\
& X4.6 & 0,571 & 0,219 & Valid \\
& X4.7 & 0,602 & 0,219 & Valid \\
\hline \multirow{5}{*}{ Kinerja } & Y.1 & 0,640 & 0,219 & Valid \\
Karyawan & Y.2 & 0,714 & 0,219 & Valid \\
& Y.3 & 0,610 & 0,219 & Valid \\
& Y.4 & 0,749 & 0,219 & Valid \\
& Y.5 & 0,754 & 0,219 & Valid \\
& Y.6 & 0,616 & 0,219 & Valid \\
& Y.7 & 0,637 & 0,219 & Valid \\
\hline
\end{tabular}

Sumber: hasil olah data 2020

4.4 Uji Asumsi Klasik

Uji Normalitas

Tabel 4 . Hasil Uji Normalitas

One-Sample Kolmogorov-Smirnov Test

\begin{tabular}{|cl|c|}
\hline & & $\begin{array}{r}\text { Unstanda } \\
\text { rdized Residual }\end{array}$ \\
\hline $\mathrm{N}$ & Mean & 80 \\
Normal Parameters $^{\mathrm{a}, \mathrm{b}}$ & Std. Deviation & .0000000 \\
& Absolute & .09545802 \\
& Most Extreme Differences Positive & .045 \\
& Negative & -.049 \\
Kolmogorov-Smirnov Z & .436 \\
Asymp. Sig. (2-tailed) & .991 \\
\hline
\end{tabular}

a. Test distribution is Normal.

b. Calculated from data.

Sumber: hasil olah data 2020

Berdasarkan Tabel 4 dapat diketahui nilai asymp.sig sebesar 0,991>0,05 sehingga dapat disimpulkan bahwa data residual berdistribusi normal karena signifikan lebih besar dari 0,05 .

Uji Heteroskedastisitas

Tabel. 5. Hasil Uji Heteroskedasitas

\begin{tabular}{llll}
\hline Variabel & Sig & Batas & Keterangan \\
\hline Self Efficacy & 0,895 & $>0,05$ & Tidak terjadi Heterokedastisitas \\
Motivasi & 0,314 & $>0,05$ & Tidak terjadi Heterokedastisitas \\
\hline
\end{tabular}




\begin{tabular}{llll}
\hline Kompensasi & 0,122 & $>0,05$ & Tidak terjadi Heterokedastisitas \\
Kepuasan Kerja & 0,174 & $>0,05$ & Tidak terjadi Heterokedastisitas \\
\hline
\end{tabular}

Sumber: hasil olah data 2020

Berdasarkan table 5 diatas tersebut bahwa dapat diketahui bahwa nilai probabilitas lebih besar dari 0,05. Dengan demikian variable yang diajukan tidak mengalami heterokedastisitas.

Uji Multikolinearitas

Tabel. 6. Hasil Uji Multikolinearitas

\begin{tabular}{llll}
\hline Variabel & Tolerance & VIF & Keterangan \\
\hline Self Efficacy & 0,540 & 1,853 & Tidak terjadi Multikolinieritas \\
Motivasi & 0,569 & 1,758 & Tidak terjadi Multikolinieritas \\
Kompensasi & 0,377 & 2,655 & Tidak terjadi Multikolinieritas \\
Kepuasan Kerja & 0,446 & 2,244 & Tidak terjadi Multikolinieritas \\
\hline
\end{tabular}

Sumber: hasil olah data 2020

Berdasarkan tabel 6 diatas diketahui nilai tolerance untuk variable self efficacy (X1), variable motivasi (X2), variable kompensasi (X3) dan variabel kepuasan kerja (X4) lebih besar dari 0,10 kemudian nilai VIF lebih kecil dari 10,00. Sehingga dapat disimpulkan bahwa data tersebut tidak mengalami atau tidak terjadi multikolinearitas.

\section{Uji Hipotesis}

Dalam penelitian ini untuk menguji variable self efficacy (X1), variable motivasi (X2), variable kompensasi (X3) dan variabel kepuasan kerja (X4) terhadap kinerja karyawan (Y) digunakan analisis regresi linier berganda. Dalam regresi linier berganda ini akan dilakukan pengujian secara simultan (Uji F) maupun secara parsial (Uji t). Untuk itu menentukan uji signifikansi yaitu uji $F$ dan uji t yaitu: Ha: apabila probabilitas $(\mathrm{p})>0,05$ berarti bahwa semua variable independent secara simultan maupun parsial mempunyai pengaruh yang signifikan terhadap variable dependen.

Uji Regresi Linier Berganda 
Tabel 7. Hasil Uji Regresi Linier Berganda

\begin{tabular}{lccccc}
\hline \multicolumn{1}{c}{ Variabel } & B & beta & t hitung & Sig t & Keterangan \\
\hline (Constant) & 0.612 & & & & \\
Self Efficacy & 0.126 & 0.164 & 2.151 & 0.035 & Signifikan \\
Motivasi & 0.138 & 0.165 & 2.224 & 0.029 & Signifikan \\
Kompensasi & 0.190 & 0.220 & 2.416 & 0.018 & Signifikan \\
Kepuasan Kerja & 0.472 & 0.468 & 5.583 & 0.000 & Signifikan \\
F hitung & 61,173 & & & & \\
Sig F & 0,000 & & & & \\
Adjusted R & 0,753 & & & & \\
square & & & & \\
$\quad$ Variabel Dependent & & & & & \\
\hline
\end{tabular}

Sumber: hasil olah data 2020

Berdasarkan tabel 7 diatas perhitungan regresi linear berganda dengan menggunakan program SPSS versi 21.0 didapat hasil sebagai berikut:

$\mathrm{Y}=0,612+0,126 \mathrm{X}_{1}+0,138 \mathrm{X}_{2}+0,190 \mathrm{X}_{3}+0,472 \mathrm{X}_{4}+\mathrm{e}$

1) Konstanta $=0,612$

Artinya jika tidak ada variable self efficacy, motivasi, kompensasi dan kepuasan kerja yang mempengaruhi kinerja karyawan, maka kinerja karyawan sebesar 0,612 satuan.

2) $b_{1}=0,126$

Artinya jika variable self efficacy meningkat sebesar satu satuan, maka kinerja karyawan akan meningkat sebesar 0,126 dengan anggapan variable bebas lain tetap.

3) $\mathrm{b}_{2}=0,138$

Artinya jika variable motivasi meningkat sebesar satu satuan, maka kinerja karyawan akan meningkat sebesar 0,138 dengan anggapan variable bebas lain tetap.

4) $b_{3}=0,190$

Artinya jika variable kompensasi meningkat sebesar satu satuan, maka kinerja karyawan akan meningkat sebesar 0,190 dengan anggapan variable bebas lain tetap.

5) $\mathrm{b}_{4}=0,472$

Artinya jika variable kepuasan kerja meningkat sebesar satu satuan, maka kinerja karyawan akan meningkat sebesar 0,472 dengan anggapan variable bebas lain tetap. 


\section{Pengujian Hipotesis parsial (Uji t)}

Uji t dikenal dengan uji parsial, yaitu dengan uji parsial, yaitu untuk menguji bagaimana pengaruh masing-masing variable bebas self efficacy, motivasi, kompensasi dan kepuasan kerja dengan variable dependen yakni kinerja karyawan. Berdasarkan table 4.7 diatas dapat diketahui hasil pengujian signifikansi menunjukkan bahwa terdapat nilai probabilitas sebesar 0,035 $<0,05$ dan $\mathrm{t}$ hitung 2,151 > t table 1,996. Maka dapat membuktikan $\mathrm{H}_{\mathrm{a} 1}$ diterima, yang berarti bahwa "self efficacy berpengaruh positif terhadap kinerja karyawan di sekertariat daerah kabupaten Gunung Kidul, Daerah Istimewa Yogyakarta".

Berdasarkan tabel 7 diatas dapat diketahui hasil pengujian signifikansi menunjukkan bahwa terdapat nilai probabilitas sebesar $0,029<0,05$ dan $t$ hitung 2,224 $>\mathrm{t}$ table 1,996. Maka dapat membuktikan $\mathrm{H}_{\mathrm{a} 2}$ diterima, yang berarti bahwa "motivasi berpengaruh positif terhadap kinerja karyawan di sekertariat daerah kabupaten Gunung Kidul, Daerah Istimewa Yogyakarta".

Berdasarkan tabel 7 diatas dapat diketahui hasil pengujian signifikansi menunjukkan bahwa terdapat nilai probabilitas sebesar $0,018<0,05$ dan $\mathrm{t}$ hitung 2,416 > t table 1,996. Maka dapat membuktikan $\mathrm{H}_{\mathrm{a} 3}$ diterima, yang berarti bahwa "kompensasi berpengaruh positif terhadap kinerja karyawan di sekertariat daerah kabupaten Gunung Kidul, Daerah Istimewa Yogyakarta".

Berdasarkan tabel 4.7 diatas dapat diketahui hasil pengujian signifikansi menunjukkan bahwa terdapat nilai probabilitas sebesar $0,000<0,05$ dan $\mathrm{t}$ hitung 5,583 $>\mathrm{t}$ table 1,996. Maka dapat membuktikan $\mathrm{H}_{\mathrm{a} 4}$ diterima, yang berarti bahwa "kepuasan kerja berpengaruh positif terhadap kinerja karyawan di sekertariat daerah kabupaten Gunung Kidul, Daerah Istimewa Yogyakarta".

\section{Pengujian Simultan (F)}

Dari hasil uji F diperoleh F hitung sebesar 61,173 dan probabilitas sebesar 0,000. Maka sesuai dengan dasar pengambilan keputusan dalam uji $\mathrm{F}$ dapat disimpulkan bahwa hipotesis diterima atau dengan kata lain self efficacy (X1), motivasi (X2), kompensasi (X3) dan kepuasan kerja (X4) secara simultan berpengaruh terhadap kinerja karyawan (Y). Sedangkan berdasarkan perbandingan nilai $\mathrm{F}_{\text {hitung }}$ dengan $F_{\text {tabel }}$ maka hasilnya $F_{\text {hitung }} 61,173>F_{\text {tabel }} 2,51$ sebagaimana dasar pengambilan keputusan dalam uji $F$ dapat disimpulkan bahwa hipotesis diterima atau dengan kata lain self efficacy (X1), motivasi (X2), kompensasi (X3) dan kepuasan kerja (X4) secara simultan berpengaruh terhadap kinerja karyawan (Y).

Koefisien Determinasi (Adjusted R2)

Berdasarkan table 4.7 di atas, diketahui nilai koefisien determinasi atau $\mathrm{R}$ Square adalah sebesar 0,753 sama dengan 75,3\%. Angka tersebut mengandung arti bahwa variable self efficacy (X1), motivasi (X2), kompensasi (X3) dan kepuasan kerja (X4) secara simultan berpengaruh terhadap kinerja karyawan $(\mathrm{Y})$ sebesar $75,3 \%$. Sedangkan sisanya $(100 \%-75,3 \%=24,7 \%)$ dipengaruhi oleh variable lain diluar persamaan regresi ini atau variable yang tidak diteliti. 


\section{SIMPULAN DAN REKOMENDASI}

Self efficacy berpengaruh positif terhadap kinerja karyawan. Hal tersebut terbukti dengan nilai t hitung sebesar 2,151 dengan nilai probabilitas 0,035 dimana angka tersebut signifikan karena nilai probabilitasnya $<0,05$. Motivasi berpengaruh positif terhadap kinerja karyawan. Hal tersebut terbukti dengan nilai t hitung sebesar 2,224 dengan nilai probabilitas 0,029 dimana angka tersebut signifikan karena nilai probabilitasnya $<0,05$.

Kompensasi berpengaruh positif terhadap kinerja karyawan. Hal tersebut terbukti dengan nilai $t$ hitung sebesar 2,416 dengan nilai probabilitas 0,018 dimana angka tersebut signifikan karena nilai probabilitasnya $<0,05$. Kepuasan kerja berpengaruh positif terhadap kinerja karyawan. Hal tersebut terbukti dengan nilai t hitung sebesar 5,583 dengan nilai probabilitas 0,000 dimana angka tersebut signifikan karena nilai probabilitasnya $<0,05$. Self efficacy, motivasi, kompensasi dan kepuasan kerja berpengaruh secara simultan terhadap kinerja karyawan. Hal tersebut terbukti dengan nilai f hitung sebesar 61,173 dengan nilai probabilitas 0,000 dimana angka tersebut signifikan karena nilai probabilitasnya $<0,05$.

Pengujian secara bersama-sama, dimana menunjukkan besarnya koefisien determinasi sebesar 0,753 sama dengan $75,3 \%$. Sedangkan sisanya $(100 \%-75,3 \%=24,7 \%)$ dipengaruhi oleh variable lain diluar persamaan regresi ini atau variable yang tidak diteliti.

\section{DAFTAR PUSTAKA}

Amin, Karami, Hossein Rezaei Dolatabadi, Saeed Rajaeepour. 2013. Analyzed the effectiviness of reward Management system on employee performance throught the Mediating Role of employee Motivation and accounting, Najafabad Branch, Islamic Azad University, Najafabad, Iran. Vol 3. No 9 ISSN: 2222-699, pp. 327-338.

Aprinawati, A. (2016). Pengaruh Kepemimpinan Dan Motivasi Kerja Terhadap Kinerja Karyawan Pt. Perkebunan Nusantara Iv (Persero) Medan. Jurnal PLANS : Penelitian Ilmu Manajemen Dan Bisnis, 11(1). https://doi.org/10.24114/plans.v11i1.9597

Bushra Fatima, Usman Ahmad, Naveed Asvir, 2011.Effect of Transformational Leadership on Employees' Job Satisfaction and Organizational Commitment in Banking Sector of Lahore (Pakistan). International Journal of Business and Social Science Vol. 2 No. 18; October 2011. pp.261.

Carmeli Abraham, 2003. The Relationship Between Emotional Intelligence and work Attitude, Behaviour and Outcomes. An Examination Among Senior Manager. Journal Of Managerial Psychology. Vol. 18. No. 8. Pp. 788-813.

Chaudhary, R., Rangnekar, S. and Barua, M.K. (2012), "Relationships between occupational self efficacy, human resource development climate, and work engagement", Team Performance Management, Vol. 18 No. 7/8, pp. 370-383.

Handoko,T.Hani.2009.Managemen,Edisi 2.Yogyakarta:BPFE

Kusuma Chandra Kirana, Dr., S.Pd., MM. and Ririn Tri Ratnasari, Dr., SE., M.Si (2017) Evaluasi Kinerja Sumber Daya Manusia (SDM). Gosyen Publishing, Sleman Yogyakarta, Yogyakarta. ISBN 978-602-1107-89-8

Maharjan, Sarita. 2012. Association between Work Motivation and Job Satisfaction of college Teachers Administrative and Management Review vol.24, No 2, pp. 45-55.

Manzoor, Q.A, (2012). Impact of Employees Motivation on Organizational Effectiveness. Business Management and Strategy, 3(1), 1-12. 
Maulana, F. (2015). Pengaruh Motivasi Intrinsik, Motivasi Ekstrinsik Dan Komitmen Organsasi Terhadap Kinerja Karyawan Pada Bank Btn Kantor Cabang Malang. Jurnal Administrasi Bisnis S1 Universitas Brawijaya, 22(1), 1-8.

Prasetya, V., Handayani, D., \& Purbandari, T. (2013). Peran Kepuasan Kerja, Self Esteem, Self Efficacy Terhadap Kinerja Individual. JRMA Jurnal Riset Manajemen Dan Akuntansi, 1(1), 59-69. Safitri, E. (2013). Erma Safitri; Pengaruh Pelatihan dan Disiplin Kerja ... Jurnal Ilmiah Manajemen, 1.

Yuli Ermawati, \& Amboningtyas, D. (2014). Pengaruh Motivasi Intrinsik, Komunikasi,Dan Kompensasi Finansial Terhadap Kinerja Karyawan Produksi Video Preparation Pada Pt Hit Polytron Yang Berimplikasi Pada Produktivitas. Jurnal Manajemen Teori Dan Terapan Tahun, 63(9), 1-7.

Iqbal, M. (2015). Pengolahan Data Regresi Linear Berganda dengan EViews 8. Jakarta: Perbanas Institute.

Li, H., Wang, J., Wu, C., \& He, Y. (2009). Are Liquidity and Information Risks Priced in the Treasury Bond Market? The Journal of Finance, 64(1), 467-503. https://doi.org/https://doi.org/10.1111/j.1540-6261.2008.01439.x 